УДК 614.841.45

\title{
ОЦІНЮВАННЯ ТЕПЛОФІЗИЧНИХ ВЛАСТИВОСТЕЙ РЕАКТИВНИХ ВОГНЕЗАХИСНИХ ПОКРИТТІВ ДЛЯ СТАЛЕВИХ КОНСТРУКЦІЙ
}

\author{
https://doi.org/10.33269/nvcz.2021.2.69-81
}

\author{
Новак C. B. ${ }^{1 *}$, ORCID iD 0000-0001-7087-318X \\ Новак M. C. ${ }^{2}$,ORCID iD 0000-0002-5888-5812 \\ Дріжд В. Л. ${ }^{3}$, ORCID iD 0000-0003-2507-7007 \\ *E-mail: novak.s.fire@gmail.com \\ ${ }^{1} /$ нститут державного управління та наукових досліджень з цивільного захисту, Україна \\ ${ }^{2}$ Національний технічний університет України «Київський політехнічний інститут \\ імені Ігоря Сікорського», Україна \\ ${ }^{3}$ /нститут фрізико-органічної хімії і вуглехімії ім. Л. М. Литвиненка, Україна
}

ІНФОРМАЦІЯ ПРО СТАТТЮ

Надійшла до редакції: 11.10.2021

Пройшла рецензування: 05.11.2021

КЛЮЧОВІ СЛОВА:

вогнестійкість, коефіцієнт

теплопровідності, покриття, що

спучується, реактивне

вогнезахисне покриття,

стандартний температурний

режим, сталева конструкція,

теплофрізичні властивості

\begin{abstract}
АНОТАЦІЯ
Математичні моделі для теплофізичних властивостей реактивного вогнезахисного покриття, що спучується, які застосовано в процедурі щодо визначення цих властивостей, наведеній в ЕN 13381-8 і ДСТУ Б В.1.1-17, не враховують повною мірою особливості процесу теплопровідності в такому покритті в умовах вогневого впливу. Це може призводити до значних похибок у встановленні його товщини, необхідної для забезпечення нормованих класів вогнестійкості сталевих конструкцій (колон і балок). У дослідженні ставилось за мету вдосконалити процедуру (що існує) з'ясування теплофізичних властивостей такого вогнезахисного покриття шляхом застосування уточненої моделі для них. За його результатами розроблено модифіковану процедуру визначення теплофізичних властивостей реактивних покриттів, що спучуються, які призначено для вогнезахисту сталевих конструкцій, в якій вихідними даними $є$ температури в печі і сталі для ненавантажених коротких конструкцій, отримані під час випробування за ЕN 13381-8 або ДСТУ Б В.1.1-17 в умовах вогневого впливу за стандартного температурного режиму. Обґрунтовано застосування в цій процедурі уточненої моделі, в якій враховано залежність коефіцієнта теплопровідності такого вогнезахисного покриття від температури, його початкової товщини і коефіцієнта поперечного перерізу сталевої конструкції. 3'ясовано алгоритм розрахунку теплофізичних властивостей покриття за модифікованою процедурою. Визначено напрями подальших досліджень, які орієнтовані на оцінювання достовірності результатів, отримуваних за розробленою модифікованою процедурою.
\end{abstract}

Постановка проблеми. 3 метою підвищення вогнестійкості сталевих конструкцій до нормованих значень на їхню поверхню наносять спеціальні вогнезахисні покриття, які можуть бути виконані із застосуванням пасивних або реактивних вогнезахисних матеріалів [1-3]. Для забезпечення нормованої вогнестійкості товщина цього покриття має бути не меншою за певну величину, за якої температура або деформація сталевої конструкції досягає критичного значення.

Для визначення значень необхідної мінімальної товщини вогнезахисного покриття для сталевих конструкцій використовують методи, які мають розрахункові процедури із застосуванням нестаціонарного

рівняння 
теплопровідності [4-6]. Сутність цих процедур полягає у встановленні коефіцієнта теплопровідності вогнезахисного покриття за отриманими експериментальними даними щодо температурного стану зразків захищених сталевих колон і балок в умовах вогневого впливу за стандартного температурного режиму [7]. Водночас процедури, які застосовують для визначення коефіцієнта теплопровідності реактивного і пасивного вогнезахисних покриттів, є однаковими. В той же час механізм теплопровідності для реактивного покриття значно відрізняється від того, який має місце для пасивного покриття. I особливості процесу теплопровідності у разі використання реактивного покриття повною мірою не враховані у процедурі визначення його теплофізичних властивостей $[5 ; 6]$, що може призводити до значних похибок у визначенні його необхідної мінімальної товщини. Отже, актуальним є розроблення і запровадження модифікованої процедури визначення теплофізичних властивостей реактивного вогнезахисного покриття, що надало б можливість підвищити точність розрахунків його необхідної мінімальної товщини, які виконують за EN 13381-8 [5] і ДСТУ Б В.1.1-17 [6].

\section{Аналіз попередніх досліджень та} публікацій. Пасивні вогнезахисні матеріали не змінюють свого фізичного стану під час нагрівання. Вони забезпечують вогнезахист конструкцій завдяки своїм теплофізичним властивостям [4; 6]. До них можуть належати матеріали, що містять воду, яка під час нагрівання випаровується, забезпечуючи поглинання теплоти. Вони можуть мати форму покриттів, що наносяться методом розпилювання, штукатурки, матів, панелей i плит [2; 3]. Теплофізичні властивості таких матеріалів залежать головним чином від температури i їх можна описати простими емпіричними залежностями.

На відміну від пасивних, склад реактивних вогнезахисних матеріалів спеціально підбирають 3 таким розрахунком, щоб забезпечити перебіг хімічної реакції під час нагрівання, 3 тим щоб змінився їх фізичний стан, у такий спосіб забезпечуючи вогнезахист конструкцій за рахунок теплоізолювального та ендотермічного ефектів [5; 6]. Вони можуть являти собою матеріал, що забезпечує утворення теплоізоляційного покриття (бути таким, що спучується), абляційний матеріал або комбінацію таких виробів [1]. Матеріали, що спучуються, збільшуються в об'ємі завдяки спінюванню в умовах теплового впливу під час пожежі. Абляційні матеріали можуть незначною мірою розширюватись завдяки утворенню звугленої речовини під час нагрівання. Для вогнезахисту сталевих конструкцій набули широкого розповсюдження реактивні вогнезахисні матеріали, що спучуються [8].

Якщо процес теплопередачі в покритті у разі використання пасивних вогнезахисних матеріалів відбувається кондуктивним шляхом, i його інтенсивність визначається тільки величинами теплофізичних властивостей матеріалу, залежних від температури, то для реактивних покриттів він $\epsilon$ значно складнішим. Це зумовлено наявністю хімічних і фізичних явищ у реактивному покритті в умовах теплового впливу під час пожежі, що спричиняють його спучування [9].

Ще у 1980-х роках Г. Каміно та співавтори [10; 11] працювали над детальним з'ясуванням механізму спучування та опублікували ряд статей iз загальним оглядом аспектів, пов'язаних із хімічними явищами та основними компонентами покриття, що спучується. Пізніше М. Брас [12; 13] та С. Бутбігот [14] провели подальші дослідження щодо хімічних і фізичних явищ, які зумовлюють спучування. Основну увагу під час проведених ними досліджень було зосереджено на тому, як покриття, що спучуються, поводять себе за наявності різних хімічних компонентів, i як ці компоненти впливають на різні аспекти поведінки, що характеризує спучування, 
зважаючи також на добавки у складі композицій.

Для вивчення процесу спучування та особливостей процесу теплопровідності в системах, що спучуються, було розроблено низку числових і математичних моделей різної складності. Інноваційну модель розробили Д. Каліостро зі співавторами [15]. У цій моделі враховано фундаментальну кінетику хімічних реакцій, а також профілі масо- i теплообміну 3 метою оцінювання температури сталевої підкладки. Модель забезпечує визначення теплоізоляційної ефективності врахуванням фактичної теплопровідності, оцінюваної як співвідношення теплопровідності i коефіцієнта спучування вогнезахисного покриття. С. Андерсон зі співавторами [16] розробили процедуру оцінювання фактичної теплопровідності звугленого шару, що утворився в результаті спучування. Він, зокрема, наголосив на впливі збільшення об'єму матеріалу на характеристики теплового реагування покриття, що спучується. Крім того, К. Ді Блазі зі співавторами [17] вивчали одномірну перехідну математичну модель для складної системи, що складалася зі сталевої підкладки та покриття, що спучується, на яку діяло теплове випромінювання. Застосовуючи спрощене рівняння теплопровідності для підкладки, він пропонує загальну модель для покриття, що складається 3 трьох компонентів, які розкладаються внаслідок перебігу незалежних одна від одної реакцій, що відбуваються з кінцевою швидкістю. В цій моделі розглядається спрощений механізм динаміки спучування матеріалу. Було розроблено також деякі інші моделі, але більшість 3 них грунтувалась на спрощеній одномірній теплопровідності крізь шар покриття, що спучується, та на напівемпіричних формулах. К. Батлер зі співавторами [18; 19], навпаки, розробили низку моделей дуже складного рівня, у тому числі для одномірної i тривимірної теплопровідності 3 метою грунтовного врахування процесу спучування.
$\mathrm{У}$ джерелах можна знайти багато описів результатів досліджень на основі цих моделей. Було запропоновано різні підходи та методології для аналізування властивостей покриттів, що спучуються, у разі впливу різних умов під час пожежі. М. Хіменес зі співавторами [20] вивчав властивості покриття, що спучується, в температурному режимі вуглеводневої пожежі [7]. Пожежі, під час яких відбувається горіння як авіаційного пального, так i горіння вуглеводнів, потужніші за звичайні з тієї причини, що під час їх перебігу досягаються дуже високі температури за доволі високої швидкості їх зростання. Г. Лі зі співавторами [21] запропонували спрощений підхід до оцінювання еквівалентного термічного опору покриттів, що спучуються, в умовах впливу пожежі, під час якої відбувається горіння матеріалів на основі целюлози, відповідно до стандартного температурного режиму [7]. М. Бартоломай зі співавторами [22] досліджували вплив зовнішнього теплового потоку і товщини покриття на теплоізоляційні властивості покриттів, що спучуються. Матеріал, що спучується, поміщений в конічний калориметр із нагрівачем, що забезпечував також визначення втрати маси, піддавали впливу потоків теплового випромінювання різної щільності, створюючи нагрівання, близьке до стандартного температурного режиму.

$X$. Дай зі співавторами [23] провели низку експериментів на сталевих елементах, захищених покриттями, що спучуються, які піддавали впливу стандартного температурного режиму. Ефективність вогнезахисту оцінювали за фактичним коефіцієнтом теплопровідності, визначеним за перетвореною формулою для розрахунку температури захищених сталевих конструкцій, наведеною в Єврокоді [24].

Л. Ван зі співавторами [25] провели низку випробувань в печі на сталевих пластинах 3 покриттями, що спучуються, які піддавали впливу нестандартних температурних режимів. Фактичні значення коефіцієнта теплопровідності оцінювали 3 
огляду на виміряні температури сталі та в печі, також користуючись перетвореною формулою з Сврокоду [24]. Дж. Андерсен у [26] визначив чотири стадії змінювання термічного опору покриттів, що спучуються, підданих впливу нестандартних температурних режимів, i також встановив, яким чином тривалість стадій та відповідні значення термічного опору залежать від швидкості нагрівання й типу сталевого профілю.

П. Шауманн зі співавторами [27] аналізували теплофізичні властивості покриття, що спучується, нанесеного 3 використанням препарату на основі органічного розчинника, в умовах «реальних» пожеж. Розглядали покриття, що спучується, призначене для вогнезахисту сталевих конструкцій в умовах пожеж, перебіг яких відбувається за стандартного температурного режиму. У першій частині дослідження теплофізичні властивості покриття оцінювали для різних значень швидкості нагрівання проведенням термогравіметричного аналізу. Показано, що втрата маси покриття чітко залежить від швидкості нагрівання на стадії реакції, результатом якої $\epsilon$ спучування. Під час другої частини експерименту ефективність теплоізоляції, забезпечуваної покриттям, досліджували, проводячи дрібномасштабні експерименти в печі.

Д. Сільва зі співавторами [28-31] показали, що багато характеристик реактивного покриття, таких як його ступінь спучування та еквівалентний коефіцієнт теплопровідності, залежать від коефіцієнта поперечного перерізу та його початкової товщини. Ці два параметри залежать також від способу нагрівання (наприклад, у печі чи в конічному калориметрі). Разом із тим такі параметри, як температура активації покриття або температура, за якої досягається мінімальне значення його коефіцієнта теплопровідності, $є$ характеристичними і не залежать від умов вогневого впливу. Визначено залежність, котра описує теплопровідність покриття, що спучується, 3 огляду на серію експериментальних даних, яку можна застосовувати для різних умов вогневого впливу.

У сучасній практиці проєктування сталевих конструкцій застосовують таблиці, в яких вказують необхідну мінімальну товщину вогнезахисного покриття, потрібну для гарантування того, що температура сталевої конструкції залишиться нижчою за задану проєктну температуру протягом заданого проміжку часу, упродовж якого має зберігатися несуча здатність цієї конструкції [8]. Наведені в цих таблицях дані щодо необхідної мінімальної товщини покриття, встановлені для різних значень проєктної температури сталі, коефіцієнта поперечного перерізу i класу вогнестійкості сталевої конструкції, характеризують його вогнезахисну здатність. Для забезпечення належного вогнезахисту 3 цих таблиць вибирають найбільш прийнятну товщину покриття 3 огляду на критичну температуру сталі, коефіцієнт поперечного перерізу, тип профілю (переріз відкритого або закритого типу), а також тип сталевої конструкції (головним чином балки або колони). Дані щодо необхідної мінімальної товщині реактивних вогнезахисних покриттів, котрі наводять в цих таблицях, визначають за результатами випробувань, методи яких наведено в EN 13381-8 [5] i ДСТУ Б В.1.1-17 [6]. Ці методи мають розрахункову складову, яка містить процедуру визначення теплофізичних властивостей реактивного вогнезахисного покриття. В європейському стандарті EN 13381-8 у цій процедурі застосовують два альтернативних підходи, в яких коефіцієнт теплопровідності покриття задають залежним від температури або незалежним від неї. В національному стандарті ДСТУ Б В.1.1-17, крім цих двох підходів, застосовують ще й альтернативний для визначення теплофізичних властивостей реактивного вогнезахисного покриття, який грунтується на розв'язанні оберненої задачі теплопровідності. Згідно 3 результатами досліджень, наведеними в [32], відхилення розрахункового значення необхідної 
мінімальної товщини реактивного вогнезахисного покриття (в тому числі й покриття, що спучується), визначеного за цими стандартами, від іiі дійсної (точної) величини може досягати декількох десятків відсотків. Однією з причин такого значного відхилення $є$ застосування спрощеної процедури визначення теплофізичних властивостей покриття, яка не повною мірою враховує особливості поведінки покриттів, що спучуються, в умовах вогневого впливу. Використання уточнених моделей для теплофізичних властивостей покриття, що спучується, напевно надасть можливість підвищити точність визначення його необхідної мінімальної товщини. Однак на підтвердження цієї гіпотези не наведені відповідні розрахунки. Отже, $\epsilon$ підстави вважати, що недостатня визначеність впливу складових математичної моделі для теплофізичних властивостей реактивного вогнезахисного покриття, що спучується, на результати визначення цих властивостей i вогнезахисної здатності такого покриття зумовлює проведення дослідження у цьому напрямі.

Мета дослідження. Метою цього дослідження було вдосконалення процедури визначення теплофізичних властивостей реактивного вогнезахисного покриття, що спучується, наведеної в EN 13381-8 і ДСТУ Б В.1.1-17, шляхом застосування для їх опису уточненої математичної моделі.

Для досягнення зазначеного розв'язували завдання щодо обгрунтування застосовної уточненої математичної моделі для теплофізичних властивостей покриття, що спучується, і розроблення алгоритму розрахунку цих властивостей в модифікованій процедурі.

Методи

вирішування дослідження. Для аналісинй завдань полягає у розгляді і вивченні положень європейського та національного стандартів EN 13381-8 і ДСТУ Б В.1.1-17, які регламентують процедури визначення теплофізичних властивостей реактивного вогнезахисного покриття, а також даних щодо особливостей i опису процесу теплопровідності в системах, що спучуються, наведених у джерелах інформації.

Виклад основного матеріалу. Процедура визначення теплофізичних властивостей реактивного покриття, що спучується, є однією зі складових методів оцінювання вогнезахисної здатності таких покриттів, призначених для захисту сталевих конструкцій, які наведено в EN 13381-8 i ДСТУ Б В.1.1-17. Початковими показниками для неї $€$ дані щодо температури в печі та сталі, отримані під час випробування ненавантажених коротких конструкцій (колон або балок) в умовах вогневого впливу за стандартного температурного режиму.

Для визначення теплофізичних властивостей покриття відповідно до EN 13381-8 застосовують базову формулу теплопровідності (1).

У разі використання підходу, в якому передбачено змінне значення $\lambda_{p}$, середні значення змінного коефіцієнта теплопровідності покриття для значень температури покриття в діапазоні від $0{ }^{\circ} \mathrm{C}$ до $1000{ }^{\circ} \mathrm{C}$ з інтервалом в $50{ }^{\circ} \mathrm{C}$, визначені для мінімальної та максимальної товщини покриття відповідно, вважають такими, що відображають теплофізичні властивості реактивного вогнезахисного покриття. Якщо використовують підхід, що передбачає стале (незалежне від температури) значення $\lambda_{p}$, то результатом визначення теплофізичних властивостей реактивного вогнезахисного покриття будуть величини коефіцієнтів регресії $c_{0}, c_{1}$ і $c_{2}$ в рівнянні (3). 


$$
\Delta \theta_{a, t}=\left[\frac{\lambda_{p, t} / d_{p}}{c_{a} \rho_{a}} \times \frac{A_{m}}{V} \times\left(\frac{1}{1+\phi / 3}\right) \times\left(\theta_{t}-\theta_{a, t}\right) \Delta t\right]-\left[\left(e^{\phi / 10}-1\right) \Delta \theta_{t}\right],
$$

де

$$
\phi=\frac{c_{p} \rho_{p}}{c_{a} \rho_{a}} \times d_{p} \times \frac{A_{m}}{V},
$$

$\Delta \theta_{a, t}-$ підвищення температури сталі за проміжок часу $\Delta t,{ }^{\circ} \mathrm{C}$;

$\Delta \theta_{t}-$ підвищення температури в печі за проміжок чacy $\Delta t,{ }^{\circ} \mathrm{C}$;

$d_{p}$ - товщина вогнезахисного покриття, м;

$A_{m} / V$ - коефіцієнт поперечного перерізу сталевої конструкції, $\mathrm{M}^{-1}$;

$\theta_{t}$ - температура в печі, ${ }^{\circ} \mathrm{C}$;

$$
\lambda_{p}=c_{0}+c_{1} \times A_{m} / V+c_{2} \times d_{p}
$$

В альтернативному підході, який наведено в ДСТУ Б В.1.1-17, на основі уточненого рівняння теплопровідності шляхом розв'язання оберненої задачі теплопровідності визначають теплофізичні властивості реактивного вогнезахисного покриття у формі залежностей коефіцієнта теплопровідності $\lambda_{p}$ і питомої об'ємної теплоємності $c_{p} \rho_{p}$ від температури. У ньому не враховано залежність теплофізичних властивостей покриття, що спучується, від його товщини i коефіцієнта поперечного перерізу сталевої конструкції.

У модифікованій процедурі запропоновано застосування уточненої моделі для теплофізичних властивостей реактивного покриття, що спучується, яка грунтується на результатах досліджень, наведених у роботах [28-31]. У цій процедурі застосовано кусково-лінійну залежність коефіцієнта теплопровідності покриття від температури (наведено на рис. 1). У діапазоні температури від кімнатної $\left(20{ }^{\circ} \mathrm{C}\right)$ до температури активації $\theta_{\text {activation }}$, яка становить $120{ }^{\circ} \mathrm{C}$ і за якої в покритті розпочинається хімічна реакція, покриття залишається інертним i його товщина $\theta_{a, t}-$ температура сталі, ${ }^{\circ} \mathrm{C}$;

$\Delta t$ - проміжок часу, с;

$\lambda_{p, t}-$ коефіцієнт теплопровідності вогнезахисного покриття в момент часу $t$ за товщини $d_{p}, \mathrm{BT} /\left({ }^{\circ} \cdot{ }^{\circ} \mathrm{C}\right)$;

$c_{a}$ - питома теплоємність сталі, Дж/(кг $\left.{ }^{\circ} \mathrm{C}\right)$;

$c_{p}$ - питома теплоємність вогнезахисного покриття, Дж/(кг $\left.{ }^{\circ} \mathrm{C}\right)$;

$\rho_{a}-$ густина сталі, кг $/ \mathrm{M}^{3}$;

$\rho_{p}$ - густина вогнезахисного покриття, кг/м ${ }^{3}$

залишається такою, що дорівнює його початковому значенню. За температури $20 \quad{ }^{\circ} \mathrm{C}$ значення коефіцієнта теплопровідності покриття $\lambda_{p, 20}$ беруть таким самим, як у сталі, оскільки активації покриття не відбувається. 3 цієї причини у діапазоні від $20{ }^{\circ} \mathrm{C}$ до $120{ }^{\circ} \mathrm{C}$ відбувається лінійне змінювання теплопровідності покриття від значення, яке відповідає теплопровідності сталі $\lambda_{a, 20}$, до значення, що має місце за температури $120{ }^{\circ} \mathrm{C}$. У разі досягнення температури активації розпочинається ендотермічна реакція 3 утворенням газоподібних речовин, що спричиняе спучування, коли товщина покриття збільшується 3 утворенням звугленої структури, яка зумовлює термічний опір проникненню теплоти. Процес поглинання теплоти покриттям для перебігу хімічної реакції, що спричиняє спучування, припиняється за температури $\theta_{\lambda, \min }$, яка становить $240{ }^{\circ} \mathrm{C}$. Ця температура відповідає мінімальному значенню коефіцієнта теплопровідності покриття. Подальше підвищення температури призводить до збільшення коефіцієнта теплопровідності покриття через властивості звугленої структури, яку було утворено в результаті процесу спучування. 


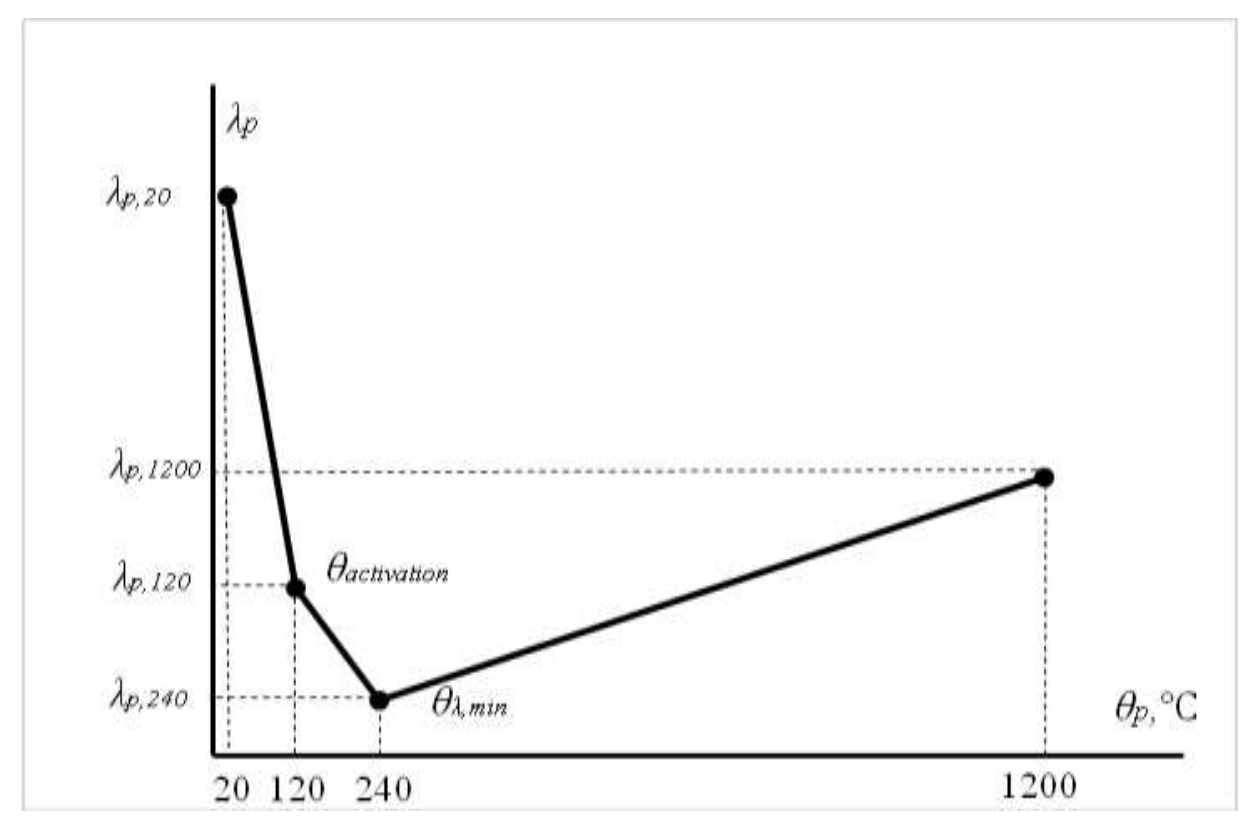

Рисунок 1 - Залежність коефіцієнта теплопровідності вогнезахисного покриття, що спучується, від температури

Графік, наведений на рис. 1, відображає температурну залежність коефіцієнта теплопровідності, яка прийнятна для індивідуальних значень початкової товщини покриття $d_{p}$ i коефіцієнта поперечного перерізу сталевої конструкції $A_{m} / V$. Залежність коефіцієнта теплопровідності від товщини $d_{p}$ i коефіцієнта $A_{m} / V$ в загальному вигляді визначається за таким рівнянням регресії [30]:

$$
\lambda_{p}\left(d_{p}, \frac{A_{m}}{V}\right)=a_{0}+a_{1} d_{p}+a_{2} \frac{V}{A_{m}}
$$

де: $a_{0}, a_{1}, a_{2}$ - коефіцієнти регресії.

3 урахуванням (4) та кусково-лінійної залежності, наведеної на рис. 1, для визначення значень коефіцієнта теплопровідності вогнезахисного покриття в модифікованій процедурі застосовано рівняння (5-10).

$$
\begin{aligned}
& \lambda_{p, 120}=a_{0,120}+a_{1,120} d_{p}+a_{2,120} \frac{V}{A_{m}} ; \\
& \lambda_{p, 240}=a_{0,240}+a_{1,240} d_{p}+a_{2,240} \frac{V}{A_{m}} ;
\end{aligned}
$$

$$
\begin{aligned}
& \lambda_{p, 1200}=a_{0,1200}+a_{1,1200} d_{p}+a_{2,1200} \frac{V}{A_{m}} \\
& \lambda_{p, 20-120}=\lambda_{p, 20}+b_{20-120}\left(\theta_{p}-20\right) \\
& \lambda_{p, 120-240}=\lambda_{p, 120}+b_{120-240}\left(\theta_{p}-120\right) \\
& \lambda_{p, 240-1200}=\lambda_{p, 240}+b_{240-1200}\left(\theta_{p}-240\right)
\end{aligned}
$$

де, $\lambda_{p, 20}, \quad \lambda_{p, 120}, \quad \lambda_{p, 240}, \quad \lambda_{p, 1200}-$ коефіцієнт теплопровідності вогнезахисного покриття за температури $20{ }^{\circ} \mathrm{C}, 120{ }^{\circ} \mathrm{C}, 240{ }^{\circ} \mathrm{C}, 1200{ }^{\circ} \mathrm{C}$, відповідно, Вт/(м $\left.\cdot{ }^{\circ} \mathrm{C}\right)$;

$\lambda_{p, 20-120}, \quad \lambda_{p, 120-240}, \quad \lambda_{p, 240-1200}-$ коефіцієнт теплопровідності вогнезахисного покриття в діапазоні температури $(20-120){ }^{\circ} \mathrm{C},(120-240){ }^{\circ} \mathrm{C}$, (240-1200) ${ }^{\circ} \mathrm{C}$ відповідно Вт/(м. $\left.{ }^{\circ} \mathrm{C}\right)$;

$a_{0,120}, a_{1,120}, a_{2,120}-$ коефіцієнти регресії за температури $120^{\circ} \mathrm{C}$;

$a_{0,240}, a_{1,240}, a_{2,240}-$ коефіцієнти регресії за температури $240{ }^{\circ} \mathrm{C}$;

$a_{0,1200}, a_{1,1200}, a_{2,1200}$ - коефіцієнти регресії за температури $1200{ }^{\circ} \mathrm{C}$.

$b_{20-120}, \quad b_{120-240}, \quad b_{240-1200}-\quad$ коефіцієнти температурної лінійної залежності $\lambda_{p}$ в діапазонах (20-120) ${ }^{\circ} \mathrm{C}, \quad(120-240){ }^{\circ} \mathrm{C}, \quad(240-1200){ }^{\circ} \mathrm{C}$, які розраховують за такими формулами (11- 13). 


$$
\begin{aligned}
& b_{20-120}=\frac{\lambda_{p, 120}-\lambda_{p, 20}}{100} \\
& b_{120-240}=\frac{\lambda_{p, 240}-\lambda_{p, 120}}{120} \\
& b_{240-1200}=\frac{\lambda_{p, 1200}-\lambda_{p, 240}}{960}
\end{aligned}
$$

Процес теплообміну в сталевій конструкції з вогнезахисним покриттям в модифікованій процедурі описується математичною моделлю теплопровідності, яка складається 3 такої системи рівнянь (14-21).

$$
\begin{gathered}
c_{a} \rho_{a} \frac{\partial \theta_{a}}{\partial t}=\frac{\partial}{\partial x}\left(\lambda_{a} \frac{\partial \theta_{a}}{\partial x}\right) \\
\text { о }<x<x_{1} ; \theta_{a}=\theta_{a}(x, t) ; \\
c_{p} \rho_{p} \frac{\partial \theta_{p}}{\partial t}=\frac{\partial}{\partial x}\left(\lambda_{p} \frac{\partial \theta_{p}}{\partial x}\right) ; \\
x_{1}<x<x_{2} ; \theta_{p}=\theta_{p}(x, t) ; \\
- \text { початкова умова: } \\
\theta_{a}(x, \text { о })=\theta_{p}(x, \text { о })=\theta_{\text {o }} \\
\text { гранична умова на обігрівній поверхні } \\
\text { вогнезахисного покриття, якщо } x=x_{2}: \\
\lambda_{p} \frac{\partial \theta_{p}}{\partial x}=\alpha^{*}\left(\theta_{t}-\theta_{p, s}\right)
\end{gathered}
$$

- гранична умова на внутрішній поверхні вогнезахисного покриття, якщо $x=x_{1}$ :

$$
\begin{gathered}
\lambda_{p} \frac{\partial \theta_{p}}{\partial x}=\lambda_{a} \frac{\partial \theta_{a}}{\partial x} \\
\boldsymbol{\theta}_{a}=\theta_{p}
\end{gathered}
$$

- гранична умова в точці теплової симетрії сталевої конструкції, якщо $x=0$ :

$$
\frac{\partial \theta_{a}}{\partial x}=0
$$

де $x$ - координата, м;

$x_{1}$ - координата внутрішньої поверхні вогнезахисного покриття, м;

$x_{2} \quad-\quad$ координата обігрівної поверхні вогнезахисного покриття, м;

$t$ - тривалість вогневого впливу, с;

$\alpha_{c}-$ коефіцієнт тепловіддачі конвекцією на обігрівній поверхні вогнезахисного покриття, який становить $25 \mathrm{BT} /\left(\mathrm{M}^{2} \cdot{ }^{\circ} \mathrm{C}\right)[33]$;

$\alpha^{*} \quad$ - сумарний коефіцієнт тепловіддачі конвекцією та тепловою радіацією на обігрівній поверхні вогнезахисного покриття, Вт/ $\left(\mathrm{M}^{2} \cdot{ }^{\circ} \mathrm{C}\right)$;

$\Phi$ - кутовий коефіцієнт, який становить $1,0[33]$

$\varepsilon_{\mathrm{p}, \mathrm{s}}-$ коефіцієнт теплового випромінювання обігрівної поверхні вогнезахисного покриття, який становить 0,8 [33];

$\varepsilon_{\mathrm{f}}$ - коефіцієнт теплового випромінювання газового середовища в печі, який становить 1,0 [33];

$$
\sigma \quad-\text { стала Стефана Больцмана, }
$$
$5,67 \cdot 10^{-8} \mathrm{BT} /\left(\mathrm{M}^{2}{ }^{\circ} \mathrm{C}^{4}\right)$;

$\theta_{\mathrm{p}, \mathrm{s}}-$ температура обігрівної поверхні вогнезахисного покриття, ${ }^{\circ} \mathrm{C}$; $20^{\circ} \mathrm{C}$;

$\theta_{0}$ - початкова температура, яка становить

$\lambda_{\mathrm{p}} \quad-\quad$ коефіцієнт теплопровідності вогнезахисного покриття, Вт/(м. $\left.{ }^{\circ} \mathrm{C}\right)$;

$\lambda_{\mathrm{a}}$ - коефіцієнт теплопровідності сталі, $\mathrm{BT} /\left(\mathrm{M} \cdot{ }^{\circ} \mathrm{C}\right)$

вогнезахисного покриття $c_{p} \rho_{p}$, за яких різниця $F$ (формула (22) між розрахунковими $\theta_{a}^{j, i}\left(x_{1}, \quad t\right) \quad \mathrm{i}$ експериментальними $\theta_{a}^{j, i}$ величинами температури сталі $\epsilon$ мінімальною та задовольняються критерії прийнятності, наведені в 13.5 EN 13381-8 [5].

$$
F=\sqrt{\frac{\sum_{j=1}^{m} \sum_{i=1}^{n}\left[\theta_{a}^{j, i}\left(x_{1}, t\right)-\theta_{a}^{j, i}\right]^{2}}{\sum_{j=1}^{m} n_{j}}},
$$

де $j$ - номер зразка для випробування, $j=1,2, \ldots$, $m ; m$ - загальна кількість зразків;

$n_{j}$ - кількість експериментальних значень температури $\theta_{a}^{j, i}$, які використовують у формулі (18), для зразка з номером $j(j=1,2, \ldots, m)$. 
Сутність розв'язання оберненої задачі теплопровідності полягає в такому. Задають початкові значення коефіцієнтів регресії $\left(a_{0,120}, a_{1,120}, a_{2,120}, a_{0,240}, a_{1,240}, a_{2,240}, a_{0,1200}\right.$, $\left.a_{1,1200,} a_{2,1200}\right)$ і питомої об'ємної теплоємності вогнезахисного покриття $c_{p} \rho_{p}$. Для одного зі зразків, яких піддавали випробуванню, за формулами 5-7 розраховують коефіцієнти теплопровідності $\lambda_{p, 120}, \lambda_{p, 240}, \lambda_{p, 1200 .}$ За формулами 11-13 визначають коефіцієнти температурної лінійної залежності $\lambda_{p}$ : $b_{20}$ $120, b_{120-240}, b_{240-1200 .} 3$ огляду на це значення $\lambda_{p, 20}$ беруть 3 Єврокоду [24]. Розв'язанням математичної моделі (8)-(10), (14)-(21) методом кінцевих різниць [34] визначають розрахункову температуру сталі $\theta_{a}^{j, i}\left(x_{l}, t\right)$. Такі ж розрахунки виконують для інших зразків, яких піддавали випробуванню. За формулою (22) визначають значення $F$. Змінюють початкове значення одного із коефіцієнтів регресії і розраховують нову величину $F$. Такі розрахунки виконують для всіх коефіцієнтів регресії і теплоємності $c_{p} \rho_{p}$. Для пошуку комбінації значень коефіцієнтів регресії і теплоємності $c_{p} \rho_{p}$, за якої величина $F \in$ мінімальною, застосовують підхід, заснований на ітераційному методі Ньютона-Гауса пошуку мінімуму функції, i методі регуляризації О. Тихонова [34].

За отриманими шляхом розв'язання оберненої задачі теплофізичними властивостями вогнезахисного покриття для кожного зразка встановлюють розрахункові дані щодо температури сталі $\theta_{a}\left(x_{1}, t\right)$. За цими даними визначають розрахункові проміжки часу $t_{\text {recal }}$ до досягнення проєктної температури сталі в діапазоні ії змінювання від $350{ }^{\circ} \mathrm{C}$ до $700{ }^{\circ} \mathrm{C}$ 3 кроком $50{ }^{\circ} \mathrm{C}$. Ці розрахункові проміжки часу порівнюють 3 відповідними експериментальними проміжками часу $t_{e x p}$, отриманими для кожного зразка, за такими трьома критеріями прийнятності, наведеними в 13.5 EN 13381-8 [5]:
- для кожного зразка жодне значення $t_{\text {recal }}$ не має перевищувати відповідного значення $t_{\text {exp }}$ більше ніж на $15 \%$;

- для кожного зразка середнє значення усіх відсоткових відмінностей $t_{\text {recal }}$ від $t_{\text {exp }}$ має бути меншим за нуль;

- більшим за нуль мають бути не більше ніж 30 \% окремих значень усіх відсоткових відмінностей $t_{\text {recal }}$ від $t_{\text {exp }}$.

Якщо всі три критерії виконуються, то вважають, що отримані шляхом розв'язання оберненої задачі значення коефіцієнтів регресії і питомої об'ємної теплоємності є такими, що відображають теплофізичні властивості вогнезахисного покриття.

Якщо це не так, то необхідно повторювати розрахунки проміжків часу $t_{\text {recal }}$, використовуючи кориговане значення $a_{0,240}$, доки не буде досягнуто узгодження 3 наведеними вище критеріями прийнятності.

Результатом визначення теплофізичних властивостей вогнезахисного покриття за модифікованою процедурою $є$ комбінація коефіцієнтів регресії $a_{0,120}, a_{1,120}, a_{2,120}, a_{0,240}$ (за необхідності коригованого), $a_{1,240}, a_{2,240}$ $\left., a_{0,1200}, a_{1,1200}, a_{2,1200}\right)$ і сталого значення питомої об'ємної теплоємності покриття $c_{p} \rho_{p}$.

Розроблена модифікована процедура призначена для визначення теплофізичних властивостей реактивних покриттів, що спучуються, які застосовують для вогнезахисту сталевих конструкцій. Ці теплофізичні властивості застосовні для створення таблиць, в яких вказують необхідну мінімальну товщину покриття, що спучується, потрібну для забезпечення нормованих класів вогнестійкості сталевих конструкцій [5]. Також зазначені властивості можуть бути використані у разі оцінювання вогнестійкості захищених сталевих конструкцій під час розгляду сценаріїв реальної пожежі [24; 33].

Однак варто зауважити, що зазначена модифікована процедура не є валідованою. Через це не можна виключати можливість отримання за нею результатів, які значно 
відрізняються від дійсних даних щодо теплофізичних властивостей реактивних вогнезахисних покриттів, що спучуються. Така невизначеність накладає обмеження на використання розробленої процедури, що може трактуватись як недолік цього дослідження. Неможливість зняти вказані обмеження в рамках цього дослідження обгрунтовує напрями подальших наукових розвідок, які, зокрема, можуть бути спрямовані на оцінювання достовірності результатів, отримуваних за цією процедурою. Під час подальшої роботи доцільно застосувати процедуру валідації методів розрахунку характеристики вогнезахисної здатності покриттів для сталевих конструкцій, яку засновано на проведенні обчислювального експерименту [35; 36], та математичну модель теплопровідності, в якій буде враховано кінетику термічної деструкції вогнезахисного покриття i динаміку змінювання його товщини в умовах вогневого впливу [18].

\section{Висновки та напрями подальших} досліджень. Під час дослідження розроблено модифіковану процедуру визначення теплофізичних властивостей реактивних покриттів, що спучуються, які призначено для вогнезахисту сталевих конструкцій. За вихідні дані взято температури в печі і сталі для ненавантажених коротких конструкцій, що отримані під час випробування за EN 13381-8 або ДСТУ Б В.1.1-17 в умовах вогневого впливу за стандартного температурного режиму.

Обгрунтовано застосування в цій процедурі уточненої моделі для теплофізичних властивостей реактивного вогнезахисного покриття, що спучується, відповідно враховано залежність коефіцієнта теплопровідності такого покриття від температури, його початкової товщини i коефіцієнта поперечного перерізу сталевої конструкції та 3'ясовано алгоритм їх розрахунку.

Визначено напрями подальших досліджень, які орієнтовані на оцінювання достовірності результатів, отримуваних за розробленою модифікованою процедурою.

\section{СПИСОК ВИКОРИСТАНИХ ДЖЕРЕЛ}

1. EAD 350402-00-1106. Reactive coatings for fire protection of steel elements. URL : https://www.eota.eu/download?file=/2015/1535-0402/ead\%20for\%20ojeu/ead\%20350402-00-1106 ojeu2017.pdf (дата звернення : 20.10.2021).

2. EAD 350140-00-1106. Renderings and rendering kits intended for fire resistant applications URL : https://www.eota.eu/download?file=/2014/14-35-0140/ead\%20for\%20ojeu/ead\%20350140-00-1106_ojeu2017.pdf ） (дата звернення : 20.10.2021).

3. EAD 350142-00-1106. Fire protective board, slab and mat products and kits. URL : https://www.eota.eu/download?file=/2014/1435-0142/ead\%20for\%20ojeu/ead\%20350142-00-1106 ojeu2017.pdf (дата звернення : 20.10.2021).

4. EN 13381-4:2013. Test methods for determining the contribution to the fire resistance of structural members - Part $4:$ Applied passive protection to steel members. EUROPEAN COMMITTEE FOR STANDARDIZATION. Management Centre : Avenue Marnix 17, B-1000 Brussels. 2013 CEN. 83 p.

5. EN 13381-8:2013. Test methods for determining the contribution to the fire resistance of structural members - Part $8:$ Applied reactive protection to steel members. EUROPEAN COMMITTEE FOR STANDARDIZATION. Management Centre : Avenue Marnix 17, B-1000 Brussels. 2013 CEN. 80 p.

6. ДСТУ Б В.1.1-17:2007. Захист від пожежі. Вогнезахисні покриття для будівельних несучих металевих конструкцій. Метод визначення вогнезахисної здатності (ENV 13381-4:2002, NEQ). [Чинний від 2008-01-01]. Київ : Мінрегіонбуд України, 2007. $66 \mathrm{c}$.

7. ДСТУ Б В.1.1-4-98*. Захист від пожежі. Будівельні конструкції. Методи випробувань на вогнестійкість. Загальні вимоги. [Чинний від 2006-01-01]. Київ : Держбуд України, 2005. 19 с.

8. Калафат К. В., Вахитова Л. Н. Каталог средств огнезащиты стальных конструкций 2017 : публикация. Метінвест, 2017.91 c.

9. Pettersson O., Magnusson S., Thor J. Fire engineering design of steel structures. Swedish Institute of Steel Construction (SBI). Stockholm, 1976. 232 p.

10. Camino G., Costa L., Trossarelli L. Study of the mechanism of intumescence in fire retardant polymers : mechanism of action in polypropylene-ammonium polyphosphate-pentaerythritol mixture. Poly. Deg. and Stab. 1984. Vol. 7. P. 25-31.

11. Camino G., Costa L. Performance and mechanism of fire retardants in polymers - A review. Poly. Deg. and Stab. 1988. Vol. 20. P. 271-294.

12. Le Bras M., Bugajny M., Lefebvre J., Bourbigot S. Use of polyurethanes as char-forming agents in polypropylene intumescent formulations. Polym. Int. 2000. Vol. 49. P. 1115-1124. 
13. Le Bras M., Camino G., Bourbigot S., Delobel R. Fire retardancy of polymers : the use of intumescence. The Royal Society of Chemistry. Cambridge, UK. 1998. 466 p.

14. Bourbigot S., Le Bras M., Duquesne S., Rochery M. Recent advances for intumescent polymers. Macromol. Mater. Eng. 2004. Vol. 289. P. 499-511.

15. Cagliostro D., Riccitello S., Clark K., Shimizu A. Intumescent coating modeling. Journal of Fire and Flammability. 1975. Vol. 6. P. 205-222.

16. Anderson C., Ketchum D., Mountain W. Thermal conductivity of intumescent chars. Journal of Fire Science. 1988. Vol. 16. P. 390410.

17. Di Blasi C., Branca C. Mathematical Model for the Nonsteady Decomposition of Intumescent Coatings. AIChE Journal. 2001. Vol. 47(10). P. 2359-2370.

18. Butler K. Physical modelling of intumescent fire retardant polymers. Building and Fire Research Laboratory. National Institute of Standards and Technology. Gaithersburg. Maryland, 1997. P. 214-228.

19. Butler K., Baum H., Kashiwagi T. Three-dimensional modelling of intumescent behaviour in fires. Fire Safety Science. Proc. 5th Int. Symp. 1997. P. 523-534.

20. Jimenez M., Duquesne S., Bourbigot S. Characterization of the performance of an intumescent fire protective coating. Surface and Coating Technology. 2006. Vol. 201. P. 523-534.

21. Assess the fire resistance of intumescent coatings by equivalent constant thermal resistance / G. Li, G. Lou, C. Zhang, L. Wang, Y. Wang. Fire Technology. 2012. Vol. 48. P. 529-546.

22. Bartholomai M., Schriever R., Schartel B. Influence of external heat flux and coating thickness on the thermal insulation properties of two different intumescent coatings using cone calorimeter and numerical analysis. Journal of Fire Materials. 2003. Vol. 27. P. $151-162$.

23. Dai X., Wang Y., Bailey C. A simple method to predict temperatures in steel joints with partial intumescent coating fire protection. Fire Technology. 2010. Vol. 46. P. 19-35.

24. ДСТУ-Н Б ЕN 1993-1-2:2010. Єврокод 3 : Проектування сталевих конструкцій. Частина 1-2. Загальні положення. Розрахунок конструкцій на вогнестійкість (EN 1993-1-2:2005, IDT). [Чинний від 2013-07-01]. Київ : Мінрегіонбуд України, 2012. $98 \mathrm{c}$.

25. Experimental study of heat transfer in intumescent coatings exposed to non-standard furnace curves / L. Wang, Y. Dong, D. Zhang, D. Zhang, C. Zhang. Fire Technology. 2015. Vol. 51. no. 1. P. 627-643.

26. Andersen J. Experimental study of the thermal resistance of intumescent coatings exposed to different heating rates. Master of Science thesis. Civil Engineering Department. Technical University of Denmark. Copenhagen. Denmark. 2015.

27. Schaumann P., Weisheim W. Effect of heating rates in natural fires on the thermal performance of a solvent-borne intumescent coating. IFireSS 2017 2nd International Fire Safety Symposium, Napoli, Italy, June 7-9 2017. P. 373-380.

28. Silva D., A. Bilotta A., Nigro E. Effect of the thermal input on the behavior of intumescent coatings. ASFE 2017 - Applications of Structural Fire Engineering, 7-8 September 2017, Manchester, UK. P. 351-360.

29. Silva D., A. Bilotta A., Nigro E. Analisi del comportamento di vernici intumescenti per la protezione al fuoco delle strutture in acciaio. Accettato per la pubblicazione negli atti della conferenza : XXVI Giornate Italiane Della Costruzione in Acciaio (28-30 Settembre 2017).

30. Bilotta A., Silva D., Nigro E. Tests on intumescent paints for fire protection of existing steel structures. Construction and Building Materials. 2016. Vol. 121. P. 410-422.

31. Bilotta A., Silva D., Nigro E. General approach for the assessment of the fire vulnerability of existing steel and composite steel concrete structures. Journal of Building Engineering. 2016. Vol. 8. P. 198-207.

32. Григорьян Н. Б., Круковский П. Г., Новак С. В. Области применения стандартизированных методов определения огнезащитной способности огнезащитных покрытий металлических конструкций : монографія. Черкаси : ЧІПБ ім. Героїв Чорнобиля НУЦЗ України, 2016. 132 с.

33. ДСТУ-Н Б В.2.6-211:2016. Проектування сталевих конструкцій. Розрахунок конструкцій на вогнестійкість. [Чинний від 2017-06-01]. Київ : Мінрегіон України, 2016. 111 с.

34. Круковский П. Г. Обратные задачи тепломассопереноса (общий инженерный подход) : монографія. Київ : Інститут технічної теплофізики НАН України, 1996. 218 с.

35. Новак С. В., Новак М. С. Валідація методів розрахунку мінімальної товщини вогнезахисних матеріалів для сталевих конструкцій. Науковий вісник : Цивільний захист та пожежна безпека. 2020. № 2 (10). С. 83-90.

36. Новак С. В., Новак М. С. Розроблення автоматизованої процедури валідації методів розрахунку характеристики вогнезахисної здатності покриттів для сталевих конструкцій. Науковий вісник : Цивільний захист та пожежна безпека. 2021. № 1 (11). C. 3-10.

\section{REFERENCES}

1. EAD 350402-00-1106. Reactive coatings for fire protection of steel elements (2017). URL https://www.eota.eu/download?file=/2015/15-35-0402/ead\%20for\%20ojeu/ead\%20350402-00-1106_ojeu2017.pdf [in English].

2. EAD 350140-00-1106. Renderings and rendering kits intended for fire resistant applications (2014). URL https://www.eota.eu/download?file=/2014/14-35-0140/ead\%20for\%20ojeu/ead\%20350140-00-1106_ojeu2017.pdf [in English].

3. EAD 350142-00-1106. Fire protective board, slab and mat products and kits (2017). URL https:/www.eota.eu/download?file=/2014/14-35-0142/ead\%20for\%20ojeu/ead\%20350142-00-1106_ojeu2017.pdf [in English].

4. EN 13381-4:2013. Test methods for determining the contribution to the fire resistance of structural members - Part 4: Applied passive protection to steel members. European Committee for Standardization. Management Centre : Avenue Marnix 17, B-1000 Brussels. 2013 CEN. 83 p. [in English].

5. EN 13381-8:2013. Test methods for determining the contribution to the fire resistance of structural members - Part 8: Applied reactive protection to steel members. European Committee for Standardization. Management Centre : Avenue Marnix 17, B-1000 Brussels. 2013 CEN. 80 p. [in English]. 
6. DSTU B V.1.1-17:2007. Vohnezakhysni pokryttia dlia budivelnykh nesuchykh metalevykh konstruktsii. Metod vyznachennia vohnezakhysnoi zdatnosti (ENV 13381-4:2002, NEQ) [Fire protective coatings for building load-bearing metal structures. Method for determining the fire protective ability (ENV 13381-4:2002, NEQ)]. K. : Minrehionbud Ukrainy, 2007. 66 s. [in Ukrainian].

7. DSTU B V.1.1-4-98*. Zakhyst vid pozhezhi. Budivelni konstruktsii. Metody vyprobuvan na vohnestiikist. Zahalni vymohy [Fire protection. Building constructions. Fire resistance test methods. General requirements]. Kyiv : Derzhbud Ukrainy, 2005.19 s. [in Ukrainian].

8. Kalafat K. V., Vakhitova L. N. (2017). Katalog sredstv ognezashchity stal'nyh konstrukcij [Catalog of steel structures fire protection 2017]: publikaciya. Metinvest, 2017. 91 s. [in Russian].

9. Pettersson O., Magnusson S., Thor J. Fire engineering design of steel structures. Swedish Institute of Steel Construction (SBI). Stockholm, 1976. 232 p. [in English].

10. Camino G., Costa L., Trossarelli L. (1984). Study of the mechanism of intumescence in fire retardant polymers: mechanism of action in polypropylene-ammonium polyphosphate-pentaerythritol mixture. Poly. Deg. and Stab. Vol. 7. P. $25-31$ [in English].

11. Camino G., Costa L. (1988). Performance and mechanism of fire retardants in polymers - A review. Poly. Deg. and Stab. Vol. 20. P. 271-294 [in English].

12. Le Bras M., Bugajny M., Lefebvre J., Bourbigot S. (2000). Use of polyurethanes as char-forming agents in polypropylene intumescent formulations. Polym. Int. Vol. 49. P. 1115-1124 [in English].

13. Le Bras M., Camino G., Bourbigot S., Delobel R. (1998). Fire retardancy of polymers: the use of intumescence. The Royal Society of Chemistry. Cambridge, UK. 466 p. [in English].

14. Bourbigot S., Le Bras M., Duquesne S., Rochery M. (2004). Recent advances for intumescent polymers. Macromol. Mater. Eng. Vol. 289. P. 499-511 [in English].

15. Cagliostro D., Riccitello S., Clark K., Shimizu A. (1975). Intumescent coating modeling. Journal of Fire and Flammability. Vol. 6. P. 205-222 [in English].

16. Anderson C., Ketchum D., Mountain W. (1988). Thermal conductivity of intumescent chars. Journal of Fire Science. Vol. 16. P. 390-410 [in English].

17. Di Blasi C., Branca C. (2001). Mathematical Model for the Nonsteady Decomposition of Intumescent Coatings. AIChE Journal. Vol. 47(10). P. 2359-2370 [in English].

18. Butler K. (1997). Physical modelling of intumescent fire retardant polymers. Building and Fire Research Laboratory. National Institute of Standards and Technology. Gaithersburg. Maryland, 1997. P. 214-228 [in English].

19. Butler K., Baum H., Kashiwagi T. Three-dimensional modelling of intumescent behaviour in fires. Fire Safety Science. Proc. 5th Int. Symp. P. 523-534 [in English].

20. Jimenez M., Duquesne S., Bourbigot S. (2006). Characterization of the performance of an intumescent fire protective coating. Surface and Coating Technology. Vol. 201. P. 523-534 [in English].

21. Li G., Lou G., Zhang C., Wang L., Wang Y. (2012). Assess the fire resistance of intumescent coatings by equivalent constant thermal resistance. Fire Technology. Vol. 48. P. 529-546 [in English].

22. Bartholomai M., Schriever R., Schartel B. (2003). Influence of external heat flux and coating thickness on the thermal insulation properties of two different intumescent coatings using cone calorimeter and numerical analysis. Journal of Fire Materials. Vol. 27. P. 151-162 [in English].

23. Dai X., Wang Y., Bailey C. (2010). A simple method to predict temperatures in steel joints with partial intumescent coating fire protection. Fire Technology. Vol. 46. P. 19-35 [in English].

24. DSTU-N B EN 1993-1-2:2010. Yevrokod 3: Proektuvannia stalevykh konstruktsii. Chastyna 1-2. Zahalni polozhennia. Rozrakhunok konstruktsii na vohnestiikist (EN 1993-1-2:2005, IDT) (2012) [Eurocode 3 : Design of steel structures. Part 1-2: General rules. Structural fire design (EN 1993-1-2:2005, IDT)] Kyiv: Minrehionbud Ukrainy, 98 s. [in Ukrainian].

25. Wang L., Dong Y., Zhang D., Zhang D., Zhang C. (2015). Experimental study of heat transfer in intumescent coatings exposed to non-standard furnace curves. Fire Technology. Vol. 51. №. 1. P. 627-643 [in English].

26. Andersen J. (2015). Experimental study of the thermal resistance of intumescent coatings exposed to different heating rates. Master of Science thesis. Civil Engineering Department. Technical University of Denmark. Copenhagen. Denmark [in English].

27. Schaumann P., Weisheim W. (2017). Effect of heating rates in natural fires on the thermal performance of a solvent-borne intumescent coating. IFireSS 2017 2nd International Fire Safety Symposium, Napoli, Italy, June 7-9. P. 373-380 [in English].

28. Silva D., A. Bilotta A., Nigro E. (2017). Effect of the thermal input on the behavior of intumescent coatings. ASFE 2017 Applications of Structural Fire Engineering, 7-8 September. Manchester, UK. P. 351-360 [in English].

29. Silva D., A. Bilotta A., Nigro E. (2017). Analisi del comportamento di vernici intumescenti per la protezione al fuoco delle strutture in acciaio. accettato per la pubblicazione negli atti della conferenza : XXVI Giornate Italiane della Costruzione in Acciaio (28-30 Settembre) [in Italian].

30. Bilotta A., Silva D., Nigro E. (2016). Tests on intumescent paints for fire protection of existing steel structures. Construction and Building Materials. Vol. 121. P. 410-422 [in English].

31. Bilotta A., Silva D., Nigro E. (2016). General approach for the assessment of the fire vulnerability of existing steel and composite steel concrete structures. Journal of Building Engineering. Vol. 8. P. 198-207 [in English].

32. Gryhorian N. B., Krukovskyi P. G., Novak S. V. (2016). Oblasty prymenenyia standartyzyrovannыkh metodov opredelenyia ohnezashchytnoi sposobnosty ohnezashchytnыkh pokrыtyi metallycheskykh konstruktsyi [Areas of application of standardized methods for determining the fire protective ability of fire protective coatings of metal structures] : monohrafiia. Cherkasy : ChIPB im. Heroiv Chornobylia NUTsZ Ukrainy, S. 132 [in Russian].

33. DSTU-N B V.2.6-211:2016. Proektuvannia stalevykh konstruktsii. Rozrakhunok konstruktsii na vohnestiikist (2016). [Design of steel structures. Calculation of structures for fire resistance]. Kyiv: Minrehion Ukrainy. $111 \mathrm{~s}$. [in Ukrainian].

34. Krukovskyi P. G. (1996). Obratnyye zadachi teplomassoperenosa (obshchiy inzhenernyy podkhod) [Inverse problems of heat and mass transfer (general engineering approach)] : monohrafiia. Kyiv: Instytut tekhnichnoi teplofizyky NAN Ukrainy. 218 s. [in Russian]. 
35. Novak S. V., Novak M. S. (2020). Validatsiia metodiv rozrakhunku minimalnoi tovshchyny vohnezakhysnykh materialiv dlia stalevykh konstruktsii [Validation of methods for calculating the minimum thickness of fire protective materials for steel structures]. Naukovyi visnyk: Tsyvilnyi zakhyst ta pozhezhna bezpeka. № 2 (10). S. 83-90 [in Ukrainian].

36. Novak S. V., Novak M. S. (2021). Rozroblennia avtomatyzovanoi protsedury validatsii metodiv rozrakhunku kharakterystyky vohnezakhysnoi zdatnosti pokryttiv dlia stalevykh konstruktsii [Development of the automated procedure of validation of methods of calculation of the characteristic of fire protective ability of coverings for steel designs]. Naukovyi visnyk: Tsyvilnyi zakhyst ta pozhezhna bezpeka. № 1 (11). S. 3-10 [in Ukrainian].

\title{
EVALUATION OF THERMAL PROPERTIES OF REACTIVE FIRE PROTECTIVE COATINGS FOR STEEL STRUCTURES
}

\author{
S. Novak', M. Novak², V. Drizhd ${ }^{3}$ \\ ${ }^{1}$ Institute of Public Administration and Research on Civil Defense, Ukraine \\ ${ }^{2}$ National Technical University of Ukraine «Igor Sikorsky Kyiv Polytechnic Institute», Ukraine \\ ${ }^{3}$ L. M. Litvinenko Institute Physical-Organic Chemistry and Coal Chemistry, Ukraine
}

\begin{tabular}{l} 
KEYWORDS \\
\hline fire resistance, \\
thermal \\
conductivity \\
coefficient, \\
intumescent \\
coating, reactive \\
fire protective \\
coating, standard \\
temperature \\
regime, steel \\
structure, thermal \\
properties.
\end{tabular}

\section{ANNOTATION}

Mathematical models of thermophysical properties of intumescent fire-retardant coating, used in the procedure for determining such properties, are described in EN 13381-8 or DSTU B V.1.1-17. These models do not fully take into account the peculiarities of thermal conductivity in such a coating under fire conditions. This can lead to significant discrepancies in determining the thickness of a coating required to ensure normalized fire resistance rates for steel structures (columns and beams). The aim of current study was to improve the existing procedure for determining thermophysical properties of intumescent fire-retardant coating by applying an updated model.

Based on the results of the study, a modified procedure for determining thermophysical properties of intumescent coatings, designed for fire protection of steel structures, was developed. The initial data for this procedure are the temperatures in the furnace and steel for unloaded short structures, obtained during tests according to EN 13381-8 or DSTU B V.1.1-17 using standard time-temperature curve.

The study substantiates the use of an updated model, which takes into account the dependence of thermal conductivity of such fire-retardant coating on temperature, initial coating thickness and cross-sectional coefficient of steel structure, in this procedure. A piecewise linear dependence of thermal conductivity of a coating on temperature was introduced. The dependence of thermal conductivity coefficient on coating thickness and cross-sectional coefficient is determined by the linear regression equations. This modified procedure also determines the algorithm for calculating thermophysical properties of intumescent fire-retardant coating. The directions for further studies were suggested, focusing on the estimation of reliability of results received when the developed modified procedure is applied 